Article

\title{
Peripheral Estates as Arrival Spaces? Conceptualising Research on Arrival Functions of New Immigrant Destinations
}

\author{
Nihad El-Kayed ${ }^{1,2, *}$, Matthias Bernt ${ }^{3}$, Ulrike Hamann ${ }^{1,2}$ and Madlen Pilz ${ }^{3}$ \\ ${ }^{1}$ Berlin Institute for Empirical Integration and Migration Research, HU Berlin, 10099 Berlin, Germany; \\ E-Mails: n.el-kayed@hu-berlin.de (N.E.-K.), ulrike.hamann@sowi.hu-berlin.de (U.H.) \\ 2 Department of Diversity and Social Conflict, Institute of Social Sciences, HU Berlin, 10099 Berlin, Germany \\ ${ }^{3}$ Leibniz Institute for Research on Society and Space, 15537 Erkner, Germany; \\ E-Mails: matthias.bernt@leibniz-irs.de (M.B.), madlen.pilz@leibniz-irs.de (M.P.) \\ * Corresponding author
}

Submitted: 18 February 2020 | Accepted: 6 May 2020 | Published: 28 July 2020

\begin{abstract}
In recent years, the question of how urban spaces support the arrival of immigrants has found increased attention among scholars. The emerging discussion uses terms like arrival cities, arrival neighbourhoods, arrival spaces, arrival contexts, or arrival infrastructures to refer to local conditions which support immigrant inclusion. This discussion, however, tends to focus empirically and conceptually on neighbourhoods or cities with long-standing migration histories. Connected to this, arrival spaces are often conceptualised as spaces with strong migrant support networks and economies, as well as with high levels of functional diversity and a high fluctuation of residents. Less focus is placed on the question of if and how destinations that lack these characteristics support the arrival of new immigrants. This contribution focuses on this by discussing existent conceptualisations of arrival spaces and contrasting them with empirical illustrations of peripheral estate neighbourhoods in east German cities that have experienced a substantial population loss since the 1990s, resulting in the partial demolition of housing and infrastructure. Since the refugee migration to Germany starting in 2015, the population dynamic in these neighbourhoods has changed substantially. We contrast these developments with the literature on arrival contexts in order to reflect the strengths and weaknesses of the concept, specifically regarding the conditions in new destinations where migrant networks and economies are still emerging, functional diversity is low, and the role of residential fluctuation is unclear. While this article draws on empirical material, its major objective is to point out the blind spots in the current discussion around arrival spaces. It develops questions and offers a research agenda that introduces a wider and more varied set of neighbourhoods into the evolving research agenda on arrival spaces.
\end{abstract}

\section{Keywords}

arrival spaces; housing; immigrant destinations; immigrant neighbourhoods; peripheral estates; refugee migration

Issue

This article is part of the issue "Urban Arrival Spaces: Social Co-Existence in Times of Changing Mobilities and Local Diversity" edited by Yvonne Franz (University of Vienna, Austria) and Heike Hanhörster (ILS-Research Institute for Regional and Urban Development, Germany).

(C) 2020 by the authors; licensee Cogitatio (Lisbon, Portugal). This article is licensed under a Creative Commons Attribution 4.0 International License (CC BY).

\section{Introduction}

In recent years, terms like arrival cities, neighbourhoods, contexts, spaces, or infrastructures have become increasingly popular among planners and scholars. They are often employed to introduce a perspective on immigrant segregation that is different from discourses that see immigrant neighbourhoods as endangering immigrant integration. Instead, the discussion on 'arrival spaces', or 'arrival neighbourhoods' emphasises that immigrant neighbourhoods offer crucial resources to newcomers. While this has proven productive in framing a new perspective 
on immigrant neighbourhoods, it also involves specific empirical and conceptual weaknesses.

Many of the characteristics commonly seen as central attributes of arrival neighbourhoods are deducted from empirical studies on neighbourhoods that have long been immigrant destinations. Consequently, the conceptualisation of arrival neighbourhoods relates mainly to inner-city neighbourhoods with a longstanding migration history, a high number of immigrant residents, and a dense and diverse local infrastructure. Yet, due to increasing housing costs and gentrification, new immigrants are more and more pushed into peripheral neighbourhoods and cities that lack many of the characteristics of these long-term immigrant destinations. We argue, therefore, that there is a strong need to extend the empirical research around arrival neighbourhoods beyond established immigrant neighbourhoods, and to introduce a wider set of contexts into the debate.

In this article, we discuss the concept of arrival neighbourhoods by looking at three cases of peripheral housing estates in East Germany that have become major destinations for immigrants only recently, during the course of the recent refugee migration to Germany that started in 2015. While we use these neighbourhoods as illustrations, the article's aim is a conceptual one. We develop a set of conceptual and research questions to refocus the current scope of research in order to widen the range of contextual conditions taken into account.

We proceed in two steps. First, we carve out central characteristics of arrival neighbourhoods as they are discussed in the literature. As a second step, we compare these with the situations in three housing estates in Schwerin, Halle (Saale), and Cottbus, which we use as empirical illustrations for our argument. All three areas were built in the German Democratic Republic (GDR) and were popular residential neighbourhoods during that time. In the 1990s, however, they experienced severe population losses that were accompanied by a downsizing (and often the demolition) of central pieces of infrastructure such as shops, cinemas, schools, and kindergartens. Since around 2015, these neighbourhoods have seen an increasing number of new immigrant residents. The foundation for this discussion is in a broader joint research project in which we observe the ongoing dynamics in these neighbourhoods (the "From Demolitions to Immigration? New Perspectives for Peripheral Estates" project at Leibniz Institute for Research on Society and Space in Erkner and HU Berlin, funded by the German Federal Ministry of Education and Research).

\section{The Discussion on Arrival Spaces and Its Blind Spots}

The role of neighbourhoods in immigrant integration is a well-established topic in urban and migration studies (Bolt, Özüekren, \& Philips, 2010; Burgess, 1928; McKenzie, 1924). While there is a common argument that immigrant enclaves are beneficial for immigrants' access to resources (Portes \& Bach, 1985; Zhou, 2009), theses which doubt this claim are often more dominant in policy formulation and in research. In particular, research on neighbourhood effects frequently starts from the question of if immigrant neighbourhoods trap immigrants in so-called 'parallel societies' and endanger their social integration (Bolt et al., 2010; Breton, 1964; Hans, Hanhörster, Polívka, \& Beißwenger, 2019).

A rather new debate-originating from the book Arrival City written by Canadian journalist Doug Saunders (2011)-uses terms like arrival city, arrival neighbourhood, arrival spaces, and arrival infrastructure to counter this view. It starts out by asking how localities provide newcomers with crucial resources and builds on positions that have been developed in past debates about immigrant neighbourhoods. The overall question put forward in this discussion, which sometimes focuses on cities and sometimes on neighbourhoods, is which structures of local life support new immigrants and provide them with information, social support, (informal) job opportunities, housing, etc. (Hans et al., 2019, p. 4).

For example, Meeus, van Heur, and Arnaut (2019, p. 1) define arrival infrastructures as the "parts of the urban fabric within which newcomers become entangled upon arrival, and where their future local or translocal social mobilities are produced as much as negotiated," and where they "find the stability to move on." Starting from such definitions of arrival contexts, the literature so far provides a number of characteristics that are seen as typical for arrival neighbourhoods. The most discussed characteristics are expanded upon below.

First, arrival spaces are often characterised as places with a high share of migrant residents and networks that are shaped by a long-standing migration history. These already existing networks are especially important as they provide new migrants access to resources such as information, job opportunities, housing options, etc. upon their arrival (Hans et al., 2019; Schillebeeckx, Oosterlynck, \& de Decker, 2019). This argument of the neighbourhood as a nexus for the provision of resources was also established in the ethnic enclave debate of the 1980s, which posited that immigrant neighbourhoods are places where crucial institutions and networks are located that help people, for example, to enter the job market (Portes \& Bach, 1985; Portes \& Manning, 1986). In this vein, Schillebeeckx et al. (2019, p. 148) show inter alia how recent migrants to an immigrant neighbourhood compensate for their lack of access to formal employment by relying "on social networks which are often forged in local community centres or local squares."

Second, arrival neighbourhoods are often characterised in terms of the density of the residential population, the built environment, and infrastructure. Dense and functionally diverse neighbourhoods that combine residential, commercial, and civic uses can offer a range of opportunity structures to help migrants make connections and access support, information, and other services. This may include shops, agencies, groceries, and 
banking services, as well as migrant established organisations and NGOs that provide legal and/or social aid (Hans et al., 2019; Schillebeeckx et al., 2019; Sidney, 2019). Neighbourhoods that are dense with this kind of infrastructure of shops and civic or social organisations are often important platforms for the dissemination of information and support, as previous research has shown (Elwert, 1982; Small, 2009; Zhou, 2009).

Third, another core characteristic of arrival spaces that is mentioned in the literature is a high rate of residential fluctuation. Kurtenbach $(2015$, p. 309$)$ postulates, e.g., that arrival neighbourhoods work as catalysts for immigrant integration, as a significant part of migrants do not settle there long-term, but instead move on to other neighbourhoods or cities. Thus, literature on arrival neighbourhoods often includes the question of immigrants moving on (Meeus et al., 2019; Schillebeeckx et al., 2019) and sometimes uses residential fluctuation as a criterion to identify arrival neighbourhoods (Dunkl, Moldovan, \& Leibert, 2019; Kurtenbach, 2015). A common reference for this assumed relationship between residential and social mobility is the Chicago School's concept of the 'zone in transition,' a term meant to characterise the areas of a city where immigrants arrive and establish themselves before they move on to neighbourhoods outside the city centre (Burgess, 1928; Kurtenbach, 2015; Schillebeeckx et al., 2019). This assumption of a close association of residential and social mobility is also akin to the basic assumption in residential assimilation approaches, which state that immigrants or minority members move to higher status neighbourhoods when they achieve a higher socio-economic position (Massey \& Denton, 1985). However, this simple association of social and residential mobility tends to overlook structural constraints, such as housing discrimination (Auspurg, Schneck, \& Hinz, 2019), that can decrease an immigrant's ability to move to higher status neighbourhoods. Furthermore, once established, the infrastructure in immigrant neighbourhoods and/or fear of discrimination in non-immigrant neighbourhoods can also affect whether immigrant residents prefer to move or stay. These and other factors complicate the simple relationship between social and residential mobility that is assumed in some of the arrival contexts literature.

Connected to this, arrival neighbourhoods are, fourthly, often conceptualised as offering affordable housing for immigrant populations and are, thus, marked by a concurrence of so-called ethnic and social segregation (Kurtenbach, 2015). This, in connection with the close association between residential and social mobility, partly echoes Loic Wacquant's (2004) argument that European immigrant neighbourhoods are 'anti-ghettos,' as they are segregated along class, not race lines. However, this argument tends to overlook that immigrants in European cities are also sorted into specific neighbourhoods and housing segments. This is, for example, due to legal regulations and housing market mechanisms, which include language barriers and discrimi- nation in housing access and rental prices (El-Kayed \& Hamann, 2018; Nicholls, 2009; Schillebeeckx et al., 2019; Winke, 2016).

In the past, immigrants were often sorted into stigmatised, less desired neighbourhoods that tended to be in the inner city. These typical arrival spaces have shifted with the increasing gentrification of inner-city neighbourhoods: Contrary to the past, many recent immigrants, therefore, tend to arrive to peripheral estates or suburbs (in North America), rather than in the densely built inner-city 'Little Italys' or 'Berlin Neuköllns' of this world (Massey, 2008; Saunders, 2018). These new arrival contexts, however, are-so far-characterised by a low prevalence of migrant residents and networks, and lack functional diversity, as they are mainly residential areas. Thus, they do not offer the same opportunities that are often discussed as serving a crucial supportive function in more traditional immigrant neighbourhoods, such as a range of immigrant small businesses, associations, and networks.

However, taking the question of what constitutes a successful arrival context as a starting point, most studies on arrival spaces are so far situated in the context of longstanding immigrant neighbourhoods or cities (see, e.g., Böckler, Gestmann, \& Handke, 2018; Kurtenbach, 2015; Nikolaeva, 2019; Schillebeeckx et al., 2019). Rarely is the concept used to look at neighbourhoods that have not yet been significantly shaped by migration but are rather new arrival destinations for immigrants (but see Dunkl et al., 2019; Steigemann, 2019). This leads to a situation where the research seldomly looks beyond established immigrant neighbourhoods and does not systematically compare these established immigrant neighbourhoods to other types of neighbourhoods.

Conceptualising characteristics and mechanisms of arrival neighbourhoods mostly on the basis of dense inner-city immigrant neighbourhoods might, therefore, lead to overlooking if and how other peripheral arrival contexts work. These contexts, however, become more and more relevant because of increasing inner-city gentrification. Looking at new, peripheral destination neighbourhoods might be especially beneficial in helping researchers evaluate more clearly which characteristics of urban space are constitutive for successful arrival spaces. Much of the current literature shows how a specific type of neighbourhood hosts structures that support immigrant newcomers but does not compare it systematically with other kinds of neighbourhoods to explore how arrival in these other neighbourhoods does (or does not) work. Thus, it is in the end difficult to say which of the above-mentioned characteristics are necessary or more helpful in supporting immigrants when they arrive. In order to know more about the quality and variations of the processes of arrival, we argue that we need to take other contexts into account and compare them with these already studied neighbourhoods. This includes researching non-supportive elements of de-facto arrival contexts, such as a lack of helpful resources. 
Despite these concerns, we find the current debate on arrival contexts helpful because it shifts the focus of the discussion that generally starts from the assumption that a concentration of immigrants hinders their integration towards supportive aspects of immigrant neighbourhoods, and offers a range of fruitful theoretical links (for an expansive discussion see Hans et al., 2019; Meeus et al., 2019). We argue that including new, peripheral destination neighbourhoods into the discussion on arrival spaces can sharpen our understanding of how and which localities (best) support the arrival of new immigrants.

We base the following on three empirical examples of East German peripheral prefabricated estates (Plattenbau, or 'prefab estates') which have only recently seen a more significant influx of immigrant residents: Mueßer Holz and Neu Zippendorf in Schwerin, Südliche Neustadt in Halle, and Sandow in Cottbus. We use these three examples not as extensive case studies that can already inform us about their potential to help migrant newcomers arrive, but rather as a foil for contrasting commonly discussed traits of arrival neighbourhoods with the contexts of these neighbourhoods. We would like to highlight that there is, first, a theoretical and empirical relevance to looking beyond typical immigrant neighbourhoods and that this, second, evokes a different set of questions than those currently posed in research on arrival neighbourhoods. With this, we would like to contribute to widening the research agenda on arrival contexts.

\section{Three East German Peripheral Prefab Estates, Seen through the Lens of the Arrival Spaces Concept}

\subsection{Migration History, Residents, and Networks}

The difficulty of applying conceptualisations of arrival neighbourhoods that have been developed in specific contexts becomes evident when the current development of large housing estates in East Germany is studied. Prefab estates make up about one fifth of the housing stock in East Germany and have experienced dramatic changes throughout the last three decades. They were built in large numbers under socialism to provide housing for a wide mix of social groups and were characterised by a high standardisation of housing types, centralised infrastructure provision, and an abundance of green space. Most prefab neighbourhoods were, at that time, rather homogenous in ethnic terms. Some prefab estates accommodated dormitories for so-called 'contract workers' (Vertragsarbeiter/innen) during the GDR times, mostly from Vietnam and Mozambique (but also from Angola, Cuba, Hungary, and other Eastern Bloc countries), but in terms of numbers, this type of immigration was rather marginal (Bade \& Oltmer, 2011, p. 77) and everyday contact between Germans and immigrants was an exception rather than the rule. In 1990, the year of German unification, two thirds of these contract worker labour migrants left Germany (Weiss, 2018, p. 128).
A new influx of immigrants occurred in the 1990s through the immigration of refugees, as well as ethnic Germans and Jewish quota refugees from the former Soviet Union (Panagiotidis, 2017; Salentin, 2007). Obtaining exact statistics about the housing locations of these immigrant groups is difficult, as statistics for smaller geographic units like cities and neighbourhoods are often only available on the basis of citizenship and do not allow for the identification of firstand second-generation immigrants that hold German citizenship. This is especially difficult when assessing the share of ethnic German immigrants, so-called (Spät-)Aussiedler/innen, who received German citizenship immediately after migrating to Germany (Haug \& Sauer, 2007; Salentin, 2007). It is, however, widely reported that many of these households settled in prefab areas (Fuchs, 1999, p. 91; Vogel, 2011, p. 19). Nevertheless, the overall share of first- and secondgeneration immigrants (with or without German citizenship, including ethnic German immigrants) is much lower in East Germany than in West Germany (Statistisches Bundesamt, 2019). In Halle-Südliche Neustadt, e.g., the share of residents without German citizenship was only $5.8 \%$ in 2000 and $9.5 \%$ in 2010 (population registry data provided by the City of Halle), which is rather low compared to immigrant neighbourhoods in West Germany.

Moreover, this international immigration into these neighbourhoods took place at a time when almost all East German cities experienced dramatic population losses (Bernt, 2009; Häußermann \& Glock, 2004). These losses were particularly pronounced in large housing estates. The population of Halle-Neustadt, to give one example, went from 89,512 down to 44,666 between 1991 and 2011 (population registry data provided by the City of Halle). Across East Germany, population decline gave rise to urban regeneration programs that aimed at 'rightsizing' cities and neighbourhoods to the size of the reduced population. As a consequence, most estates experienced the demolition of residential buildings, as well as social and technical infrastructure in the 2000s. Population shrinkage and large-scale restructuring plans were, furthermore, accompanied by a take-over of large parts of the housing stock by new financial investors. As the business strategy of these investors is often based on letting flats for very competitive prices to welfare recipients (Bernt, Colini, \& Förste, 2017), urban shrinkage and the takeover of large stocks by private investors resulted in a massive influx of low-income households. Moreover, contrary to other landlords, these investors seem to be less discriminatory in their letting practices, with refugees (especially from the Middle East) having often found it easier to rent a flat in these stocks. We can assume that the major reason for this is that private companies have usually purchased low-quality residential blocks in peripheral locations, often with high vacancyrates. As their business model is based on achieving full occupancy and minimising rental losses (Bernt et al., 2017), they are more likely to not discriminate between 
different types of residents than investors with longerterm orientations. As a consequence, these investors not only accepted more migrant housing applications, but proactively targeted the immigrant market, at least in some cases. This facilitated a rapid increase of the concentration of immigrants in the neighbourhoods where private investors held substantial parts of the stocks.

Figures 1 and 2 show the share of non-German citizens in the neighbourhoods. Again, we face the problem that the data shown here does not include firstand second-generation immigrants with German citizenship and, therefore, underestimates the migrant population. However, we can still see that it is only after 2015 that East German prefab neighbourhoods faced a quickly increasing share of migrant households, the main part consisting of refugee immigrants from Syria. This is not only a rise in relative share, as Figure 1 shows, but also a rise in absolute numbers; in Schwerin-Mueßer $\mathrm{Holz} / \mathrm{Neu}$ Zippendorf, the total number of residents with foreign citizenship in the year 2010 was 1,804, compared to 4,363 in 2019. In Halle-Südliche Neustadt, this number rose from 1,435 in 2010 to 4,682 in 2018, and in Cottbus-Sandow from 508 in 2010 to 1,532 in 2018.

The main part of this increase consists of Syrian refugees (see Figure 2). Their share of the local population was close to zero in 2010, while they now form the largest group of non-German citizens in all three neighbourhoods. In Schwerin-Mueßer Holz/Neu Zippendorf there was only one resident with Syrian nationality in 2010, while there were 1,544 in 2019. In Halle-Südliche Neustadt, the number of Syrian nationals rose from 66 in 2010 to 2,253 in 2018 and in Cottbus-Sandow from 39 in 2015 to 702 in 2018. Thus, in a relatively short time, Syrians became the prevalent immigrant group in neighbourhoods previously characterised by having only a moderate share of migrant groups, mostly com- ing from Eastern Europe and the former Soviet Union. Additionally, all three neighbourhoods saw increases, albeit much smaller, in migrants from different origins (e.g., from Afghanistan, Romania, and Eritrea), which have added to the increasing share of immigrants in the neighbourhoods.

The increased number of refugee residents is also an effect of a residential constraint (Wohnsitzauflage) that has been in effect since 2016. This constraint prescribes that refugees who have acquired an asylum status have to take up residency for at least three years in the regional state (Bundesland) where their asylum application was processed (El-Kayed \& Hamann, 2018).

This situation raises a number of questions regarding the role of existing migrant networks in arrival neighbourhoods, as new immigrants cannot easily connect to longestablished networks and newly built networks might not be as efficient in providing access to information and resources (e.g., job opportunities). Connected questions include, for example, if and how new immigrants find ways to access such resources via other channels (e.g. via state programs or non-migrant networks); if and how immigrants are able to connect to pre-existing, smaller immigrant communities with a different migration history and language (immigrants from the former Soviet Union in this case); how new immigrant networks establish themselves and start to build support structures; and if and how immigrants living in these new arrival places might be able to substitute needed support by accessing networks located elsewhere.

\subsection{Density and Diversity of the Built Environment and Other Infrastructure}

The three discussed neighbourhoods are marked by a low degree of functional diversity and a strong depen-

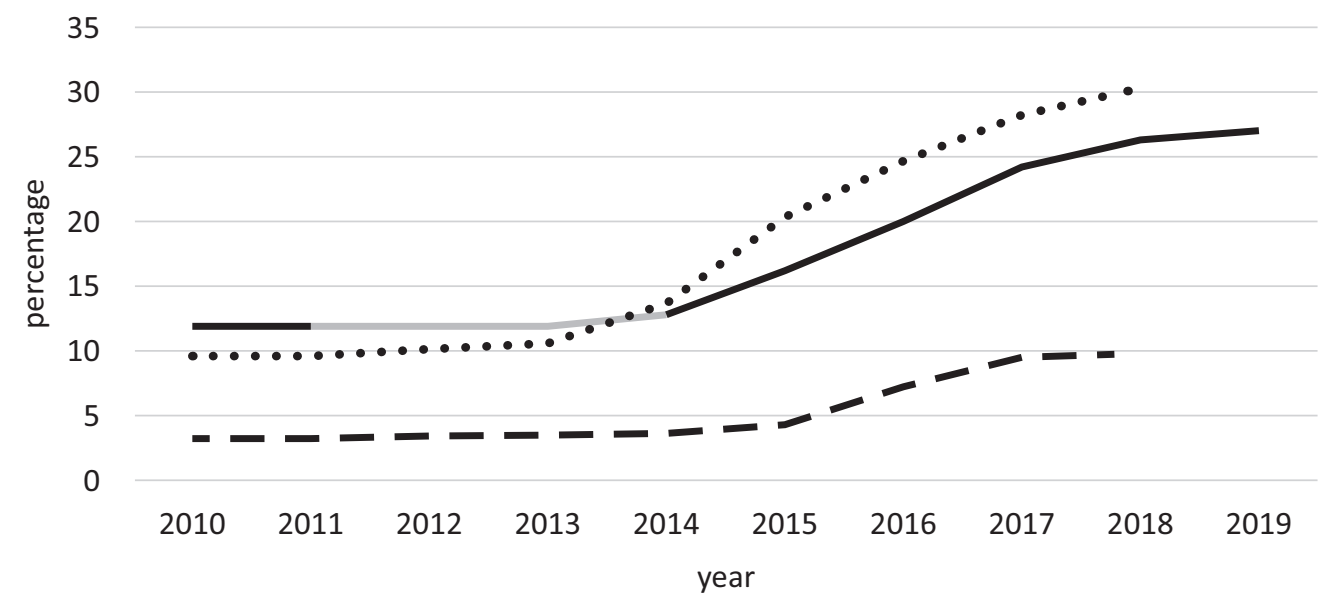

$$
\begin{aligned}
& \text { - Mueßer Holz/Neu Zippendorf (Schwerin) (no data for 2011-2013) } \\
& \text { _. - südl. Neustadt (Halle) } \\
& \text { — - Sandow (Cottbus) }
\end{aligned}
$$

Figure 1. Percentage of the population that are not German citizens. Source: Own compilation of population registry data. 


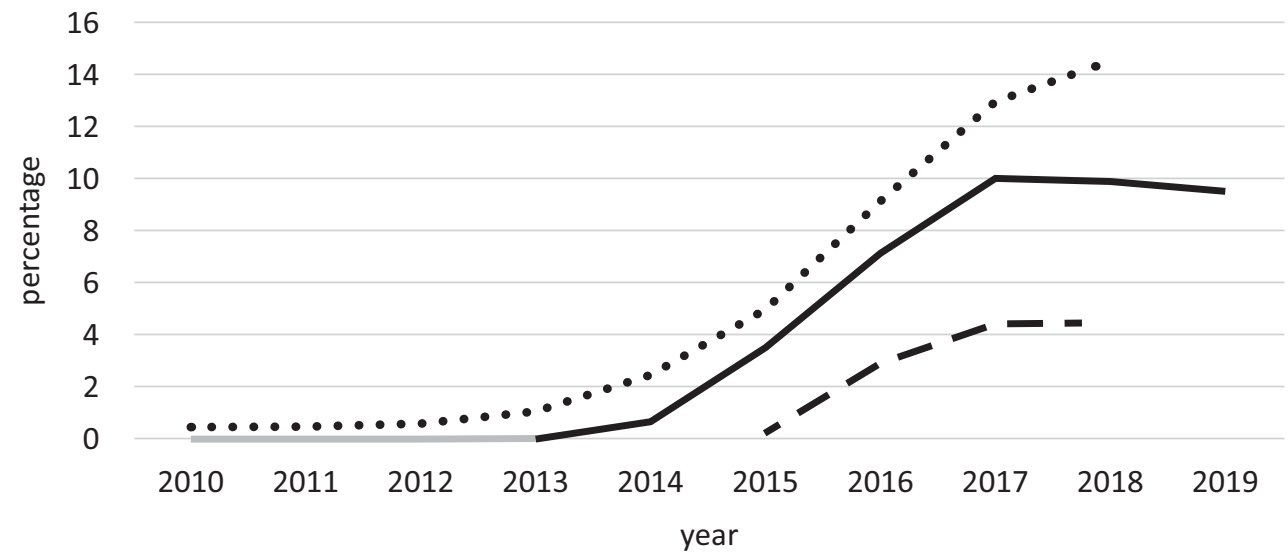

_. Mueßer Holz/Neu Zippendorf (Schwerin) (no data for 2011-2013)
_ - südliche Neustadt (Halle)
- Sandow (Cottbus) (no data before 2015)

Figure 2. Percentage of the population that are Syrian nationals. Source: Own compilation of population registry data.

dency of much of the infrastructure on state-based policies, while parts of the arrival cities literature puts a strong focus on migrant resident's entrepreneurial agency (Saunders, 2011).

In the arrival spaces literature, strong immigrant entrepreneurial infrastructures are described as opportunity structures where people can meet others and access support, information, and services. Such entrepreneurial structures are, however, not very strong in the three neighbourhoods, as they were built as residential estates and only allow for a limited level of functional diversity. Existing shopping facilities are concentrated in a handful of shopping centres that are usually dominated by chain stores. Connected to this, and the rather small-scale migration history so far, the neighbourhoods offer few migrant-run small businesses like groceries, repair shops, or restaurants. The existence of the few local immigrant businesses can, therefore, hardly be seen as a pull factor for locally concentrated immigration. The reality is rather the opposite: Migrants have been pushed into the prefab estates and once they have arrived there, they started to build some initial businesses (see Figure 3).

In contrast to this very low density of migrant entrepreneurial activity, there are different social and civic organisations located in the neighbourhoods that offer cultural and sports activities, language and other courses, counselling, and other kinds of support (e.g., support for those facing difficult familial circumstances). Among them are examples of migrant established organisations that are connected to the migration of the 1990s (e.g., German Ukrainian Cultural Centre in Schwerin) or founded by recent immigrants (Maan e.V. in Schwerin). Other organisations are not limited to, but include, immigrants in their target group (e.g., the Die Platte lebt Association in Schwerin).

The municipalities support different projects of these associations temporarily, whether on the basis of the national program Soziale Stadt, which specifically tar- gets poor neighbourhoods, or on the basis of integration funds provided by the federal states. Therefore, and according to an interview with the Coordinator of Integration Policies in Schwerin (30 January 2020) such publicly funded social infrastructure is more prevalent in the disadvantaged neighbourhoods we look at than in other parts of the city.

This raises the question of which role public funding from different scales and institutional actors (municipalities, regional states, etc.) play in the development of local civil society structures (see also Meeus et al., 2019; Sidney, 2019). Against the background of our illustrative cases, several questions come to mind that should be considered regarding the density, the organisation, and the functionality of infrastructure in new arrival contexts: How dense do entrepreneurial or civic infrastructures need to be in order to fulfil arrival functions for a wider immigrant population? Which functions of migrant organisations, small-scale businesses, and other forms of self-organised infrastructures can be substituted via publicly funded programs, and how efficient are they at fulfilling migrant's needs? What role do state activities play in setting the framework for the entrepreneurial and civic society agency of immigrants?

This also touches upon the role that state conceptualisations of integration play in the provision of local arrival infrastructure (see also Steigemann, 2019). The relatively new migration of refugees into East German prefab estates is accompanied by a strong interest of the local state in managing the process of their arrival, which can be analysed by looking at municipal concepts of integration. For our argument, we want to highlight some contradictory aspects within the local states' concepts of integration in the context of our three illustrative cases.

On the one hand, all three cities have a progressive understanding of integration that considers it as a multidirectional process of change that includes all groups of society (Stadt Halle, 2017, p. 84), emphasises the ne- 

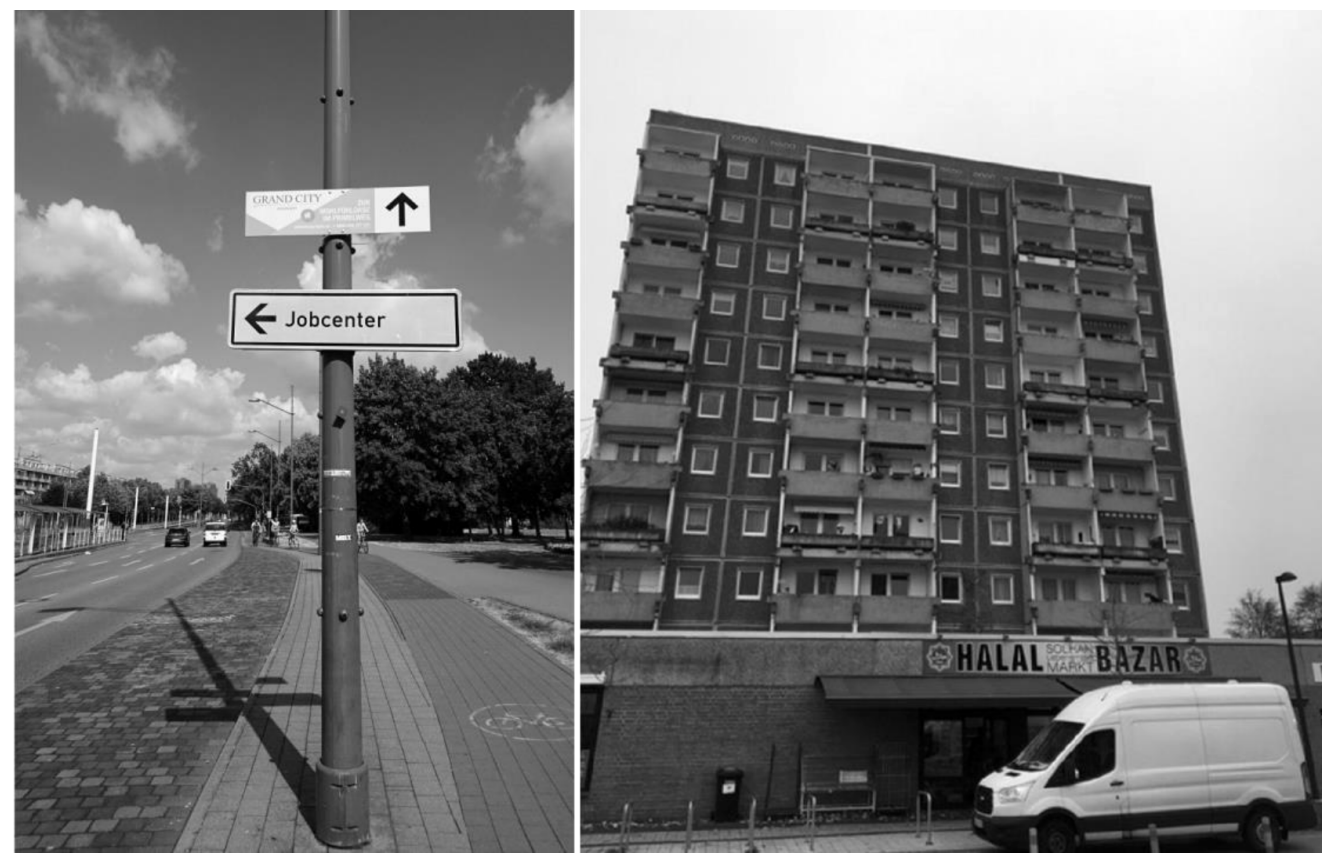

Figure 3. The job centre sign in Halle, Südliche Neustadt, and an Arabic supermarket in Mueßer Holz/Neu Zippendorf (Schwerin).

cessity of creating equal opportunities for social and political participation, and provides an acknowledgement of difference without a demand for assimilation (Ruhl, 2018 , p. 6). On the other hand, the cities have a problematising perspective of migration in relation to urban space. In these cities, the spatial concentration of migrants in certain neighbourhoods has become a target issue for state policies; For example, the city of Schwerin has reached the "limit of its ability to integrate" incoming refugees after 2015, as noted in its integration policy paper (Ruhl, 2018, p. 14, authors' translation), and the city of Cottbus applied for a halt to further influxes of refugees to the city (Bundesregierung, 2018, p. 2; Jedicke, 2018). Additionally, the cities are now alarmed by a recent study that found high levels of social segregation in all three of them (Helbig \& Jähnen, 2019) exactly in the neighbourhoods where the number of new refugee residents is high. In these cities, we can see different reaction strategies to the alarm about ethnic segregation. On the one hand, Cottbus tries to prevent refugees from taking up residence in the city (for a discussion of the questionable effects of this kind of zoning regulations, see Çağlar, 2001). In Halle, an understanding of certain neighbourhoods such as Halle-Neustadt as 'arrival neighbourhoods' or Ankunftsquartiere (Stadt Halle, 2019, p. 60) has started to form; this is, however, controversial and debated (as shown in a workshop on Halle, Südliche Neustadt, organised by the Urban Planning Department of the City of Halle in November 2019). If and how these kinds of policy discussions result in different infrastructures on the ground remains to be seen. Furthermore, it needs to be analysed if policies that try to constrain refugee settlement will have the intended effects. Other studies imply that such measures to stop immigration in specific urban areas often fail to bring about their stated objective (Lanz, 2015).

In short, all three cities of our case study register a recent growth in immigration in specific urban areas, mainly prefab neighbourhoods, and are working to respond to the fear of increasing social segregation. When discussing arrival spaces in the contexts of these neighbourhoods, this development evokes the question of what local narratives around migration and segregation lead to which local policies, and if the policies will support or hinder the arrival of new immigrant residents. In connection to the entrepreneurial and organisational structures in the neighbourhoods discussed above, a relevant question is if state-organised local infrastructure is able to substitute for the functions of what we might call classical arrival infrastructure, such as migrant enterprises and organisations. This includes asking which policies produce sufficient levels of the dense and functionally diverse arrival infrastructure needed to build successful arrival neighbourhoods and which do not.

\subsection{Spatial and Social Mobility}

In some of the arrival neighbourhoods literature, a high level of residential mobility is regarded as a criterion typical for arrival neighbourhoods, as these areas are seen as places to move on from, as catalysts for social and spatial mobility (Kurtenbach, 2015; Meeus et al., 2019). Based on this, immigrants are seen not as contained, but rather as being pushed through these neighbourhoods in the process of their social mobility.

Again, East German estates offer a puzzling picture when compared to this view: Residential mobility has in fact been very high in the subsequent decades, but this 
has been more the result of a "housing market of extremes" (Expertenkommission, 2000) caused by the combination of the population decline and an oversupply of housing typical for East Germany through the 1990s and 2000s. Consequently, drivers and patterns of segregation and residential mobility tended to be determined by a broad mix of factors, with international migration being of minor importance-until very recently.

In a nutshell, the segregation history of East German estates since the reunification of Germany can be described as follows: While these neighbourhoods were characterised by a broad social mix (yet ethnically very homogenous) under socialism, this picture changed dramatically in the 1990s (Harth, Scheller, \& Herlyn, 1998). Two factors were crucial for this change. The first is that the deindustrialisation of East Germany caused a massive outmigration of residents, mostly to more prosperous regions in West Germany. Due to the demographic composition of most estates (with a higher share of younger people), this disproportionately affected large housing estates. The second factor is that the suburbanisation experienced in East Germany in the 1990s provided new housing choices for middle-class inhabitants, with many leaving the cities for the suburbs. The outcome of these developments were massive population losses in the East German prefab estates (Expertenkommission, 2000; Hannemann, 2003; Oswalt, 2004, 2005).

As described above, international immigration into these prefab estate areas only developed slowly, mostly in the shadows of the dominating process of population losses and 'urban shrinkage.' Population fluctuation was, therefore, very high for a long period but mostly not in connection with international immigration. Thus, it is much too early to tell whether recent immigrants are likely to stay or move on to other neighbourhoods, cities, or countries. In sum, in-migration of foreign households is a very recent phenomenon here, and it is happening against a fairly peculiar mix of circumstances. As a consequence, it is difficult to tell if prefab estates will become new arrival neighbourhoods, in the sense that they work as steppingstones for social and spatial mobility, or not.

As discussed above, the influx of refugee immigrant populations into these prefab estates is mostly being driven by a combination of high welfare dependency, a lack of affordable alternatives (together with the fact that rents are only paid up to an administratively defined level; see Bernt et al., 2017), and the residential constraint (Wohnsitzauflage) that limits the residential mobility of immigrants with an asylum status. This creates "internal border regimes" (El-Kayed \& Hamann, 2018) that push immigrants into the least desired neighbourhoods in urban areas. While such institutional pressures are not a novel phenomenon, they lead us to ask whether the term arrival neighbourhoods actually refers to places with specific qualities that attract immigrants in order to find the resources to move on, or if the term might in some instances provide cover for discriminatory practices.
The potential for immigrant social mobility in new immigrant destination neighbourhoods might depend on how successful the establishment of migrant infrastructures and networks are or how alternatives such as state-organised structures might be able to act as a substitute for them. The question of spatial mobility is, furthermore, a crucial question for the planning of social infrastructure, which is vital for social mobility (e.g., schools). This includes the question of if new immigrant residents see these peripheral neighbourhoods as desirable residential locations or if they want to move to other neighbourhoods, e.g., to neighbourhoods with longerstanding migration histories in West Germany, as quickly as they can. City administrations often voice the fear that these neighbourhoods might stop being immigration destinations as new immigrant residents might move on as soon as the residential constraint no longer applies. Then, the city administrations would again be confronted with the problem of a shrinking population. A population dynamic that results in fast-changing population sizes and compositions might, therefore, pose a huge challenge for cities to be able to react in time to provide crucial social infrastructure like schools and kindergartens.

Finally, the idea of residential fluctuation in the discussion of arrival neighbourhoods seems to assume a close relationship between spatial and social mobility. However, there is a wide range of research that calls this assumption into question. Research on the effects of the residential neighbourhood on different dimensions of social inequality and integration often does not find any, small, or mixed effects (Bolt et al., 2010; van Ham, Maney, Bailey, Simpson, \& Maclennan, 2012). Other research has shown that people also access resources located in neighbourhoods outside their residential ones (Hanhörster \& Weck, 2016; Zhou, 2009). Thus, it might not be the residential neighbourhood that needs to provide certain functions, but another arrival neighbourhood close by. Based upon this, the importance of residential location for social mobility is called into question. The question then is: What kinds of arrival infrastructures need to be located in the residential neighbourhood and which can be located further away? This includes asking if and how people build social ties in urban contexts (Nast \& Blokland, 2014; Small, 2009). With its focus on residential fluctuation, the arrival contexts literature offers an interesting link to discuss such aspects beyond what is normally considered in the standard neighbourhood effects literature (Hans et al., 2019, pp. 5-7); However, there is a need to develop more explicit and refined theses about the relationship between social and spatial mobility.

\section{Discussion and Conclusion}

Looking at peripheral estates in East German cities, which are only now becoming destinations for a larger number of immigrants, invites questions that are often out of the focus of research on traditional immigrant gateways. As discussed, the (still developing) literature 
on arrival neighbourhoods describes them as places with (a) a significant share of immigrant residents and networks, due to a long-standing migration history, that are (b) dense in terms of their built environment and functional diversity, are (c) marked by a high degree of spatial mobility and that (d) often have a more affordable housing market and a concentration of socio-economically disadvantaged households.

Recently, however, more and more new immigrants are being pushed to locate in peripheral cities and neighbourhoods that have not been major immigrant destinations so far. In this article we contrasted this predominant characterisation of arrival neighbourhoods with the emerging situation in three East German peripheral neighbourhoods, which were used as illustrative empirical examples. These new arrival contexts often (a) lack a long-standing migration history and a significant share of immigrant residents and networks, (b) are less densely built environments without significant functional diversity, and (c) are contexts where the role it plays in the spatial and social mobility of new immigrants is far from clear. This, we argue, raises new questions for the debate on the arrival functions of local contexts and shows a need to expand the research agenda currently connected to terms like arrival neighbourhoods, arrival spaces, arrival infrastructure, or arrival contexts.

First, in classic arrival neighbourhoods, prior migration offers points of entry and resource access; earlier migrants might help successive migrants find housing, jobs, information, and a sense of home. We know less about if and how new immigrants find access to such resources in contexts that have not, thus far, been shaped by prior migration. Connected questions worth exploring in future research are if and in what way immigrant networks can be substituted by non-immigrant networks and organisations, and how local immigrant networks emerge, or if immigrant residents connect to non-local networks instead.

Second, immigrant neighbourhoods are often understood as dense, inner-city areas that offer varied infrastructure, including a high concentration of immigrant organisations, businesses, and more. However, in the three neighbourhoods we looked at, the situation is different. The built environment is less dense and offers fewer possibilities for functional diversity. Furthermore, the existing civic and social service infrastructures are characterised by a stronger state influence than is often imagined in more entrepreneurial accounts of immigrants' self-organisation efforts. This poses the question of if neighbourhoods can develop effective arrival support functions under conditions of less dense and less functionally diverse infrastructure. Regarding the role of the state, a crucial aspect is how narratives around migration, integration, and segregation shape local policies and infrastructure on the ground. This is specifically important for understanding neighbourhood contexts-as the ones discussed here-where the state might have a stronger role in providing civic and social infrastructures on the ground.
Third, some of the arrival contexts literature includes the question of how and why migrants move on from arrival spaces. However, in the three neighbourhoods we looked at, it is too early to assess patterns of residential mobility for the new immigrant residents. This uncertainty also affects the planning of social infrastructure, such as schools and social service programmes that might be crucial for the social mobility of immigrants. Furthermore, this raises questions like: Can neighbourhoods only be regarded as arrival spaces when a significant proportion of their population has moved on? Can social mobility go hand in hand with spatial immobility? These questions demonstrate that the relationship between residential and social mobility is a complex topic that needs to be studied in varying contexts.

In summary, the concept of arrival contexts offers a much-needed emphasis on the supportive functions of immigrant neighbourhoods and offers an alternative framing for discourses on immigrant segregation. However, we argue that more systematic comparative work is needed in order to answer questions about the directionality of the effects and the existence of specific support mechanisms that neighbourhoods with different levels and compositions of migrant populations, different densities and mixtures in terms of the built environment and infrastructures, and differences in population fluctuation, offer immigrant populations or do not.

Based on our discussion of the concept of arrival spaces in the context of East German peripheral housing estates, we see the following issues as points of departure for further research. First, will the development of typical arrival structures catch on or stall in these peripheral housing estates? Second, are these neighbourhoods able to offer substitutions for arrival infrastructure identified in previous research (e.g., can state-provided social organisations substitute functions of migrant organisations)? Third, if arrival infrastructures are not present in the residential neighbourhood, are residents able to access them outside of their neighbourhood (Hanhörster \& Weck, 2016; Zhou, 2009)? Fourth, how do these developments affect the relationship between residential and social mobility? All these aspects will affect if the neighbourhoods we looked at will develop structures that support the arrival of new immigrant residents or not.

\section{Acknowledgments}

The authors thank the two anonymous reviewers who took the time to review this article, as well as the journal's editors for their helpful comments and suggestions. Special thanks to Heike Hanhörster for her fruitful input, suggestions, and comments during an internal research workshop in 2019. This article was developed in the context of the research project StadtumMig-Vom Stadtumbauschwerpunkt zum Einwanderungsquartier? Neue Perspektiven für periphere Großwohnsiedlungen ("From Demolitions to Immigration? New Perspectives for Peripheral Estates"), funded by the German Federal 
Ministry of Education and Research (Funding Program Zukunftsstadt, FKZ: 01UR1802A, 01UR1802C).

\section{Conflict of Interests}

The authors declare no conflict of interests.

\section{References}

Auspurg, K., Schneck, A., \& Hinz, T. (2019). Closed doors everywhere? A meta-analysis of field experiments on ethnic discrimination in rental housing markets. Journal of Ethnic and Migration Studies, 45(1), 95-114.

Bade, K. J., \& Oltmer, J. (2011). Germany. In K. J. Bade, P. C. Emmer, L. Lucassen, \& J. Oltmer (Eds.), The encyclopedia of migration and minorities in Europe from the 17th century to the present (pp. 65-82). Cambridge: Cambridge University Press.

Bernt, M. (2009). Partnerships for demolition: The governance of urban renewal in East Germany's shrinking cities. International Journal of Urban and Regional Research, 33(3), 754-769.

Bernt, M., Colini, L., \& Förste, D. (2017). Privatization, financialization and state restructuring in East Germany: The case of am Südpark. International Journal of Urban and Regional Research, 41(4), 555-571.

Böckler, S., Gestmann, M., \& Handke, T. (2018). Neuzuwanderung in Duisburg-Marxloh: Bulgarische und rumänische Zuwanderer und Alteingesessene im Ankunftsquartier [New immigration in DuisburgMarxloh: Bulgarian and Romanian immigrants and established residents in the arrival neighbourhood]. Wiesbaden: Springer Fachmedien.

Bolt, G., Özüekren, S., \& Philips, D. (2010). Linking integration and residential segregation. Journal of Ethnic and Migration Studies, 36(2), 169-186.

Breton, R. (1964). Institutional completeness of ethnic communities and the personal relations of immigrants. American Journal of Sociology, 70(2), 193-205.

Bundesregierung. (2018). Antwort der Bundesregierung auf die Kleine Anfrage der Abgeordneten Filiz Polat, Luise Amtsberg, Britta Haßelmann, weiterer Abgeordneten und der Fraktion Bündnis 90/Die GrünenDrucksache 19/1410-Zur Wohnsitzregelung für Asylberechtigte und subsidiär Schutzberechtigte [Answer of the Federal Government to the 'small inquiry' of the members of Parliament Filiz Polat, Luise Amtsberg, Britta Haßelmann, other members of Parliament and the parliamentary group Bündnis 90/Die Grünen-Printed matter 19/1410-Regarding residency rules for beneficiaries of asylum and subsidiary protection] (Printed matter 19/1608). Berlin: Deutscher Bundestag.

Burgess, E. W. (1928). Residential segregation in American cities. The Annals of the American Academy of Political and Social Science, 140(1), 105-115.

Çağlar, A. S. (2001). Constraining metaphors and the transnationalisation of spaces in Berlin. Journal of Ethnic and Migration Studies, 27(4), 601-613.

Dunkl, A., Moldovan, A., \& Leibert, T. (2019). Innerstädtische Umzugsmuster ausländischer Staatsangehöriger in Leipzig: Ankunftsquartiere in Ostdeutschland? [Inner-city relocation patterns of foreign nationals in Leipzig: Arrival neighbourhoods in East Germany?]. Stadtforschung und Statistik: Zeitschrift des Verbandes Deutscher Städtestatistiker, 32(2), 60-68.

El-Kayed, N., \& Hamann, U. (2018). Refugees' access to housing and residency in German cities: Internal border regimes and their local variations. Social Inclusion, 6(1), 135-146.

Elwert, G. (1982). Probleme der Ausländerintegration. Gesellschaftliche Integration durch Binnenintegration? [Problems of the integration of foreigners. Social integration through internal integration?]. Kölner Zeitschrift für Soziologie und Sozialpsychologie, 34(4), 717-731.

Expertenkommission. (2000). Wohnungswirtschaftlicher Strukturwandel in den neuen Bundesländern. Bericht der Kommission [Structural change of the housing economy in the new federal states. Report of the commission] (Bauforschung, T 2949). Stuttgart: Fraunhofer-Informationszentrum Raum und Bau Verlag.

Fuchs, M. (1999). Die Wohnungssituation der Aussiedler [The housing situation of the 'repatriated']. In R. K. Silbereisen, E.-D. Lantermann, \& E. Schmitt-Rodermund (Eds.), Aussiedler in Deutschland. Akkulturation von Persönlichkeit und Verhalten ['Repatriates' in Germany. Acculturation of personality and behaviour] (pp. 91-104). Wiesbaden: Springer.

Hanhörster, H., \& Weck, S. (2016). Cross-local ties to migrant neighborhoods: The resource transfers of outmigrating Turkish middle-class households. Cities, 59, 193-199.

Hannemann, C. (2003). Schrumpfende Städte in Ostdeutschland: Ursache und Folgen einer Stadtentwicklung ohne Wirtschaftswachstum [Shrinking cities in East Germany: Causes and consequences of urban development without economic growth]. Bundeszentrale für politische Bildung. Retrieved from https://www.bpb.de/apuz/27519/schrumpfendestaedte-in-ostdeutschland-ursache-und-folgeneiner-stadtentwicklung-ohne-wirtschaftswachstum

Hans, N., Hanhörster, H., Polívka, J., \& Beißwenger, S. (2019). Die Rolle von Ankunftsräumen für die Integration Zugewanderter. Eine kritische Diskussion des Forschungsstandes [The role of arrival spaces for the integration of immigrants. A critical discussion of the state of research]. Raumforschung und Raumordnung, 77(5), 1-14.

Harth, A., Scheller, G., \& Herlyn, U. (1998). Segregation in ostdeutschen Städten: Eine empirische Studie [Segregation in East German cities: An empirical study]. Opladen: Leske + Budrich.

Haug, S., \& Sauer, L. (2007). Zuwanderung und Inte- 
gration von (Spät-)Aussiedlern: Ermittlung und Bewertung der Auswirkungen des Wohnortzuweisungsgesetzes [Immigration and integration of (late) migrants: Determination and evaluation of the impacts of the Residence Assignment Act]. Nuremberg: Federal Office for Migration and Refugees.

Häußermann, H., \& Glock, B. (2004). New trends in urban development and public policy in Eastern Germany: Dealing with the vacant housing problem at the local level. International Journal of Urban and Regional Research, 28(4), 919-929.

Helbig, M., \& Jähnen, S. (2019). Wo findet "Integration" statt? Die sozialräumliche Verteilung von Zuwanderern in den deutschen Städten zwischen 2014 und 2017 [Where does "integration" take place? The socio-spatial distribution of immigrants in German cities between 2014 and 2017] (Discussion Paper 2019-003). Berlin: Wissenschaftszentrum Berlin.

Jedicke, H. (2018, November 30). Nach dem Flüchtlingsstopp. So ist die Lage in Salzgitter, Cottbus und Pirmasens [After the 'refugee stop.' The situation in Salzgitter, Cottbus and Pirmasens]. FOCUS. Retrieved from https://www.focus.de/politik/ deutschland/nach-dem-fluechtlingsstopp-so-istdie-lage-in-salzgitter-cottbus-und-pirmasens_id_ 9991290.html

Kurtenbach, S. (2015). Ankunftsgebiete: Segregation als Potenzial nutzen [Arrival areas: Using segregation as a potential]. In A. El-Mafaalani, S. Kurtenbach, \& K. P. Strohmeier (Eds.), Auf die Adresse kommt es an. Segregierte Stadtteile als Problem- und Möglichkeitsräume begreifen [It's the address that counts. Understanding segregated urban districts as areas of problems and opportunities] (pp. 306-328). Weinheim: Beltz Verlag.

Lanz, S. (2015). Berlin aufgemischt: Abendländisch, multikulturell, kosmopolitisch? Die politische Konstruktion einer Einwanderungsstadt [Berlin stirred up: Western, multicultural, cosmopolitan? The political construction of an immigration city]. Bielefeld: transcript Verlag.

Massey, D. S. (Ed.). (2008). New faces in new places: The changing geography of American immigration. New York, NY: Russell Sage Foundation.

Massey, D. S., \& Denton, N. A. (1985). Spatial assimilation as a socioeconomic outcome. American Sociological Review, 50(1), 94-106.

McKenzie, R. D. (1924). The ecological approach to the study of the human community. American Journal of Sociology, 30(3), 287-301.

Meeus, B., van Heur, B., \& Arnaut, K. (2019). Migration and the infrastructural politics of urban arrival. In $B$. Meeus, K. Arnaut, \& B. van Heur (Eds.), Arrival infrastructures: Migration and urban social mobilities (pp. 153-177). Cham: Springer.

Nast, J., \& Blokland, T. (2014). Social mix revisited: Neighborhood institutions as setting for boundary work and social capital. Sociology, 48(3), 482-499.
Nicholls, W. (2009). Book Review: Urban outcasts: A comparative sociology of advanced marginality. Urban Studies, 46(10), 2239-2243.

Nikolaeva, A. (2019). Rebordering Europe from the margins since the 1970s: A history of a layered arrival infrastructure for the mobile poor in Amsterdam. In B. Meeus, K. Arnaut, \& B. van Heur (Eds.), Arrival infrastructures: Migration and urban social mobilities (pp. 103-130). Cham: Springer.

Oswalt, P. (2004). Schrumpfende Städte: Internationale Untersuchungen [Shrinking cities: International investigations] (Vol. 1). Ostfildern-Ruit: Hatje Cantz Verlag.

Oswalt, P. (2005). Schrumpfende Städte: Handlungskonzepte [Shrinking cities: Concepts for action] (Vol. 2). Ostfildern-Ruit: Hatje Cantz Verlag.

Panagiotidis, J. (2017). Postsowjetische Migranten in Deutschland [Post-Soviet migrants in Germany]. Bundeszentrale für politische Bildung. Retrieved from https://www.bpb.de/apuz/243862/ postsowjetische-migranten-in-deutschlandperspektiven-auf-eine-heterogene-diaspora

Portes, A., \& Bach, R. L. (1985). Latin journey: Cuban and Mexican immigrants in the United States. Berkeley, CA: University of California Press.

Portes, A., \& Manning, R. D. (1986). The immigrant enclave: Theory and empirical examples. In J. Nagel \& S. Olzak (Eds.), Competitive ethnic relations (pp. 47-68). Orlando, FL: Academic Press.

Ruhl, A. (2018). Integrationskonzept der Landeshauptstadt Schwerin 2017-2018 [Integration concept of the state capital Schwerin 2017-2018]. Schwerin: Landeshauptstadt Schwerin, der Oberbürgermeister.

Salentin, K. (2007). Die Aussiedler-Stichprobenziehung ['Repatriate' sampling]. Methoden, Daten, Analysen (mda), 1(1), 25-44.

Saunders, D. (2011). Arrival city: How the largest migration in history is reshaping our world. London: Windmill Books.

Saunders, D. (2018). Der Umbau der Zwischenstadt [The reconstruction of the 'in-between-city']. In K. Schäfer (Ed.), Aufbruch aus der ZwischenstadtUrbaniserung durch Migration und Nutzungsmischung [Departure from the 'in-between-city': Urbanisation through migration and mixed usage] (pp. 21-40). Bielefeld: transcript Verlag.

Schillebeeckx, E., Oosterlynck, S., \& de Decker, P. (2019). Migration and the resourceful neighborhood: Exploring localized resources in urban zones of transition. In B. Meeus, K. Arnaut, \& B. van Heur (Eds.), Arrival infrastructures: Migration and urban social mobilities (pp. 131-152). Cham: Springer.

Sidney, M. (2019). NGOs as arrival infrastructures: Pathways to inclusion for immigrants in the U.S. and Canada. In B. Meeus, K. Arnaut, \& B. van Heur (Eds.), Arrival infrastructures: Migration and urban social mobilities (pp. 53-80). Cham: Springer.

Small, M. L. (2009). Unanticipated gains: Origins of net- 
work inequality in everyday life. Oxford: Oxford University Press.

Stadt Halle. (2017). ISEK Halle Saale 2025: Integriertes Stadtentwicklungskonzept [ISEK Halle Saale 2025: Integrated urban development concept]. Halle: Stadt Halle (Saale), der Oberbürgermeister.

Stadt Halle. (2019). Bildung gemeinsam gestalten: Bildungsleitbild für die Stadt Halle (Saale) [Shaping education together: Educational mission statement for the city of Halle (Saale)]. Halle: Stadt Halle (Saale), der Oberbürgermeister.

Statistisches Bundesamt. (2019). Bevölkerung und Erwerbstätigkeit: Bevölkerung mit Migrationshintergrund-Ergebnisse des Mikrozensus 2018 [Population and employment: Population with migration background-Results of the microcensus 2018] (Series 1, 2.2). Wiesbaden: Destatis.

Steigemann, A. M. (2019). First arrivals: The sociomaterial development of arrival infrastructures in Thuringia. In B. Meeus, K. Arnaut, \& B. van Heur (Eds.), Arrival infrastructures: Migration and urban social mobilities (pp. 179-205). Cham: Springer.

van Ham, M., Maney, D., Bailey, N., Simpson, L., \& Maclennan, D. (Eds.). (2012). Neighbourhood effects research: New perspectives. Dordrecht: Springer.
Vogel, C. (2011). Familiale Generationenbeziehungen russischsprachiger Migranten-Forschungsstand und Forschungsbedarfe [Generational family relations of Russian-speaking migrants: Current state of the research and research needs] (Working Paper No. 9). Vechta: Zentrum Altern und Gesellschaft.

Wacquant, L. (2004). Ghetto. In N. J. Smelser \& P. B. Baltes (Eds.), International encyclopedia of the social \& behavioral sciences (pp. 121-126). Amsterdam: Elsevier.

Weiss, K. (2018). Zuwanderung und Integration in den neuen Bundesländern [Immigration and integration in the new federal states]. In F. Gesemann \& R. Roth (Eds.), Handbuch lokale Integrationspolitik [Handbook on local integration policy] (pp. 125-143). Wiesbaden: Springer Fachmedien.

Winke, T. (2016). Menschen mit Migrationshintergrund zahlen elf Euro mehr Miete pro Monat [Persons with migration background pay eleven euros more rent per month]. DIW-Wochenbericht, 83(47), 1133-1143.

Zhou, M. (2009). Contemporary Chinese America: Immigration, ethnicity, and community transformation. Philadelphia, PA: Temple University Press.

\section{About the Authors}

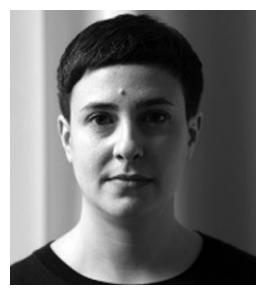

Nihad El-Kayed is a Postdoctoral Researcher at the Berlin Institute for Empirical Integration and Migration Research (BIM) and the Department of Diversity and Social Conflict at the Institute of Social Sciences (both at HU Berlin). Her research focuses on citizenship and migration in urban contexts, neighbourhood research, social networks and social capital, and political participation, as well as sport and migration.

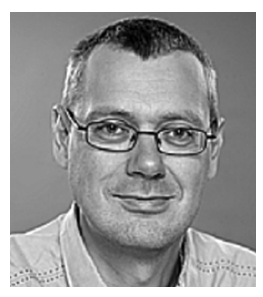

Matthias Bernt (PhD) works as a Senior Researcher at the Leibniz Institute for Research on Society and Space (IRS) in Erkner and as an Adjunct Professor at the Institute for Social Sciences at the HU Berlin. His research focuses on the broad field of interrelations between urban development and urban governance, with a strong focus on urban shrinkage, gentrification, and migration.

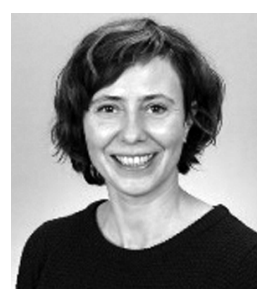

Ulrike Hamann (PhD 2014, Political Science, Goethe University Frankfurt/Main) is a Postdoctoral Researcher at the Department of Diversity and Social Conflict at the Institute for Social Sciences at $\mathrm{HU}$ Berlin. She researches and teaches on questions of racism, migration, and the city. At the Berlin Institute for Empirical Integration and Migration Research (BIM), she has researched and published on the motives and structures of welcome initiatives after 2015 , on access to housing for refugees, and on neighbourhoods of welcome in German cities and peripheral estates.

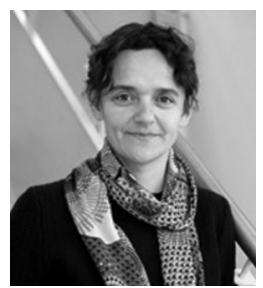

Madlen Pilz (PhD) is currently a Researcher at the Leibniz Institute for Research on Society and Space (IRS). Her main research topics include critical urban and migration studies, post-socialist spaces, and everyday life studies and protests. In recent years she has carried out research and published about the post-socialist reconstruction of urban space in Tbilisi and postmigrant urban spaces and struggles in Munich. 